Fumihiko Mabuchi · Zentaro Yamagata $\cdot$ Kenji Kashiwagi Kiyotaka Ishijima $\cdot$ Sa Tang $\cdot$ Hiroyuki Iijima Shigeo Tsukahara

\title{
A sequence change (Arg158GIn) in the leucine zipper-like motif region of the MYOC/TIGR protein
}

Received: September 11, 2000 / Accepted: November 17, 2000

\begin{abstract}
The myocilin/trabecular meshwork-inducible glucocorticoid response (MYOC/TIGR) gene was identified as a gene that caused open angle glaucoma (OAG). Singlestrand conformation polymorphism analysis and subsequent sequence analysis were performed for the $M Y O C /$ $T I G R$ gene in 120 unrelated Japanese OAG patients with increased intraocular pressure (IOP), 116 unrelated $\mathrm{OAG}$ patients without increased IOP, and 106 unrelated control subjects without glaucoma. An Arg158Gln sequence change in the leucine zipper-like motif (LZM) region in the myosin-homology domain was found in 2 OAG patients with or without increased IOP, and in a 56-year-old control subject without glaucoma. This is the first report of missense sequence change in the LZM region of the MYOC/TIGR protein in subjects showing various phenotypes, including a control subject. These findings suggest that Arg158Gln in the LZM region is probably a rare nondisease-causing polymorphism, despite its important role in this region, because it was found in a control subject, although Arg158Gln was previously reported as a probable diseasecausing mutation.
\end{abstract}

Key words The $M Y O C / T I G R$ gene $\cdot G L C 1 A \cdot$ Open angle glaucoma $\cdot$ Japanese $\cdot \operatorname{Arg} 158 \mathrm{Gln} \cdot$ Leucine zipper-like motif

F. Mabuchi $\cdot$ Z. Yamagata $(\bowtie) \cdot$ S. Tang

Department of Health Sciences, Yamanashi Medical University, 1110

Shimokato, Tamaho-cho, Nakakoma-gun, Yamanashi 409-3898,

Japan

Tel. +81-55-273-9566; Fax +81-55-273-7882

e-mail: zenyamagata@res.yamanashi-med.ac.jp

K. Kashiwagi $\cdot$ H. Iijima $\cdot$ S. Tsukahara

Department of Ophthalmology, Yamanashi Medical University,

Yamanashi, Japan

K. Ishijima

Department of Ophthalmology, Uenohara City Hospital, Yamanashi, Japan

\section{Introduction}

Glaucoma is one of the most common eye diseases and can potentially result in bilateral blindness. It was estimated that nearly 66.8 million people worldwide would be affected by glaucoma by the year 2000 (Quigley 1996). The disease is characterized by an excavated optic nerve head and the progressive loss of visual field.

The myocilin/trabecular meshwork-inducible glucocorticoid response (MYOC/TIGR) gene was identified as a gene that caused open angle glaucoma (OAG) (Stone et al. 1997). It consists of three exons and encodes 504 amino acid residues (Adam et al. 1997). The amino acid sequence is highly homologous to the myosin in the N-terminal region and to the olfactomedin in the C-terminal region (Kubota et al. 1997). The myosin-homology domain contains a leucine zipper-like motif (LZM) (Kubota et al. 1997), and this kind of motif found in the tropomyosin-like zipper protein is thought to be involved in interactions with myosin (Bikle et al. 1993). These findings suggest that LZM in the MYOC/ TIGR protein may play an important role in maintaining the normal function of the MYOC/TIGR protein. Kubota et al. (2000) reported that missense sequence change (Arg158Gln) in this motif region was probably responsible for OAG, although the olfactomedin-homology domain of the MYOC/TIGR protein appears to be the focus of pathogenic mutations in patients with OAG (Adam et al. 1997). In this study, we found Arg158Gln in subjects showing various phenotypes, including a control subject without glaucoma, we report the genotype and phenotypes of these patients.

\section{Subjects and methods}

Subjects

Informed consent was obtained and peripheral blood was collected from 120 unrelated Japanese OAG patients with increased intraocular pressure (IOP), 116 unrelated 
Table 1. Characteristics of subject population

\begin{tabular}{|c|c|c|c|}
\hline & $\begin{array}{l}\text { OAG patients } \\
\text { with increased IOP } \\
(n=120)\end{array}$ & $\begin{array}{l}\text { OAG patients } \\
\text { without increased IOP } \\
(n=116)\end{array}$ & $\begin{array}{l}\text { Control subjects } \\
(n=106)\end{array}$ \\
\hline Age at diagnosis (years; mean $\pm \mathrm{SD}$ ) & $53.1 \pm 15.9$ & $59.0 \pm 13.1$ & $64.8 \pm 11.1$ \\
\hline Range & $13-87$ & $22-84$ & $41-84$ \\
\hline \multicolumn{4}{|l|}{ Sex } \\
\hline Male & $77(64.2)$ & $44(37.9)$ & $33(31.1)$ \\
\hline Female & $43(35.8)$ & $72(62.1)$ & $73(68.9)$ \\
\hline Family history of glaucoma & $27(22.5)$ & $24(20.7)$ & $0(0)$ \\
\hline Maximum known intraocular pressure $(\mathrm{mmHg} ;$ mean $\pm \mathrm{SD})$ & $29.3 \pm 9.9$ & $18.6 \pm 1.9$ & $15.0 \pm 2.8$ \\
\hline Range & $22-74$ & $14-21$ & $8-20$ \\
\hline
\end{tabular}

Data values are numbers (percentages) unless otherwise indicated

OAG, Open angle glaucoma; IOP, intraocular pressure

Japanese OAG patients without increased IOP, and 106 unrelated Japanese control subjects without glaucoma. The study protocol was approved by the Ethics Committee of Yamanashi Medical University. The age at diagnosis in the OAG patients with increased IOP ranged from 13 to 87 years (mean $\pm \mathrm{SD}, 53.1 \pm 15.9$ years), and the age in the OAG patients without increased IOP ranged from 22 to 84 years (mean $\pm \mathrm{SD}, 59.0 \pm 13.1$ years). In the $\mathrm{OAG}$ patients with increased IOP, 27 patients had a family history of glaucoma $(22.5 \%)$, and in the OAG patients without increased IOP, 24 patients had a family history of glaucoma $(20.7 \%)$. The mean maximum known IOP was $29.3 \pm$ $9.9 \mathrm{mmHg}$ (range, 22 to $74 \mathrm{mmHg}$ ) in the OAG patients with increased IOP, and the mean maximum known IOP was $18.6 \pm 1.9 \mathrm{mmHg}$ (range 14 to $21 \mathrm{mmHg}$ ) in the $\mathrm{OAG}$ patients without increased IOP. The age in control subjects ranged from 41 to 84 years (mean $\pm \mathrm{SD}, 64.8 \pm 11.1$ years); their mean maximum known IOP was $15.0 \pm 2.8 \mathrm{mmHg}$ (range 8 to $20 \mathrm{mmHg}$ ) (Table 1 ).

\section{Mutation analysis}

Genomic DNA was purified with a DNA Extractor WB Kit (Wako, Osaka, Japan), and screened for the MYOC/TIGR gene mutations, using single-strand conformation polymorphism (SSCP) analysis. The three exons of the MYOC/ $T I G R$ gene were amplified by dividing the two longer exons into overlapping polymerase chain reaction (PCR) products. The 13 PCR amplicons were obtained using the primer pairs reported by Alward et al. (1998). The PCR reactions were carried out in a total volume of $20 \mu \mathrm{l}$, containing $100 \mathrm{ng}$ genomic DNA, 4 pmol of each primer, $0.2 \mathrm{mM}$ of each dNTP, $1.5 \mathrm{mM}$ of $\mathrm{MgCl}_{2}$, and $0.5 \mathrm{U}$ of Taq polymerase (TaKaRa Taq; Takara, Tokyo, Japan) in a thermocycler (model AB-1820; ATTO, Tokyo, Japan). Amplification was carried out with an initial denaturation at $94^{\circ} \mathrm{C}$ for $5 \mathrm{~min}$, followed by 25 cycles of denaturation at $94^{\circ} \mathrm{C}$ for $30 \mathrm{~s}$, annealing at $55^{\circ} \mathrm{C}$ for $30 \mathrm{~s}$, and extension at $72^{\circ} \mathrm{C}$ for $1 \mathrm{~min}$. A final extension at $72^{\circ} \mathrm{C}$ for $7 \mathrm{~min}$ completed the reactions. After amplification, $4 \mu \mathrm{l}$ of stop solution (90\% formamide, $5 \mathrm{mM}$ ethylenediamine tetraacetic acid (EDTA), $0.05 \%$ bromophenol blue, $0.05 \%$ xylene cyanol) was added to $4 \mu \mathrm{l}$ of each sample. Amplification products were loaded on polyacrylamide gels (GeneGel Excel 12.5/24 Kit; stacking gel, $\mathrm{T}=6 \% ; \mathrm{C}=3 \%$; separating gel, $\mathrm{T}=12.5 \% ; \mathrm{C}=2 \%$; Amersham Pharmacia Biotech, Amersham Place, UK), after denaturation for $5 \mathrm{~min}$ at $95^{\circ} \mathrm{C}$, and electrophoresed at $20 \mathrm{~W}$ for $1 \mathrm{~h}$ and $40 \mathrm{~min}$ at the most appropriate temperature for amplification products $\left(5^{\circ} \mathrm{C}, 10^{\circ} \mathrm{C}\right.$, or $\left.15^{\circ} \mathrm{C}\right)$, using an electrophoresis unit (GenePhor; Amersham Pharmacia Biotech). After the electrophoresis, the gels were stained with silver nitrate in an automated gel stainer (Hoefer; Amersham Pharmacia Biotech). Abnormal PCR products identified by SSCP analysis were sequenced using fluorescent dideoxynucleotides in an automated sequencer (model 310; ABI Prism Biosystem, Foster City, CA, USA). All sequencing was bidirectional.

\section{Results}

Of the 236 OAG patients, 2 had a heterozygous G-to-A change at nucleotide 473 in the first exon of the MYOC/ $T I G R$ gene, resulting in an amino acid change from arginine to glutamine: Arg158Gln (Fig. 1). This sequence change was also found in 1 of the 106 control subjects without glaucoma. These 3 subjects simultaneously had heterozygous G-to-A changes at $83 \mathrm{bp}$ upstream of the promoter site and at nucleotide 227, resulting in an amino acid change from arginine to lysine: Arg76Lys, which was found in 14 of the 236 patients with OAG and in 8 of the 106 control subjects.

\section{Case 1}

A 43-year-old man with no family history of glaucoma had had blurred vision in his right eye at the age of 38 , when the IOP was high in both eyes. He was referred to us because of insufficient reduction in IOP despite his having used topical antiglaucoma medications. At the initial examination, his best corrected visual acuity was 1.2 in each eye. His IOP was $23 \mathrm{mmHg}$ in the right eye and $28 \mathrm{mmHg}$ in the left eye with $0.5 \%$ timolol maleate (Timoptol; Banyu, Tokyo, Japan) and $0.1 \%$ dipivefrine hydrochloride (Pivalephrine; Santen, Osaka, Japan) twice daily. Gonioscopy revealed a widely 


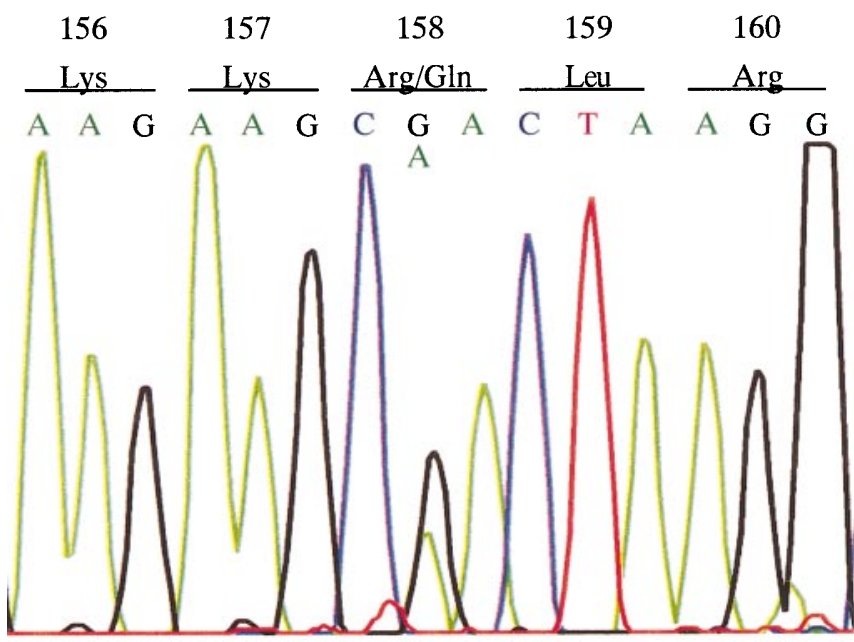

Fig. 1. Electrophorograms resulting from automated sequencing, showing Arg158Gln. A heterozygous G-to-A change at nucleotide 473 in the first exon of the MYOC/TIGR gene, resulting in an amino acid change from arginine to glutamine
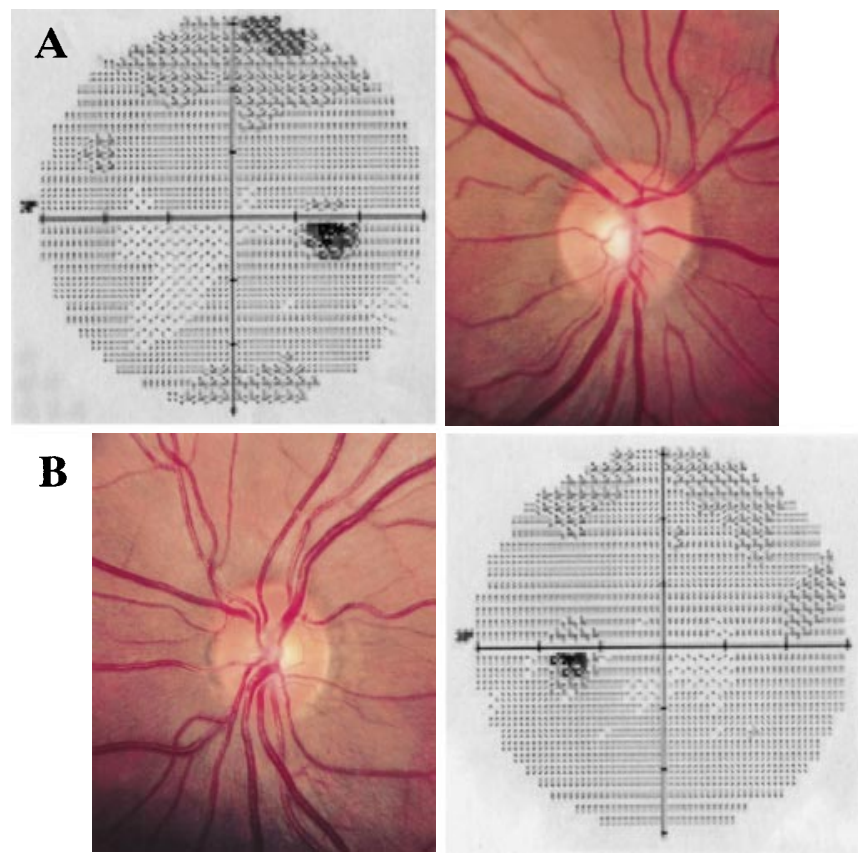

Fig. 2A,B. Visual field and optic disc of patient (case 1) with Arg158Gln in the MYOC/TIGR protein. A Right eye; B left eye. Although glaucomatous disc cupping and visual field defect were not detected, his maximum known intraocular pressure (IOP) was remarkably high $(36 \mathrm{mmHg})$

open angle in both eyes. Although ophthalmoscopic examination revealed no glaucomatous changes in the optic disc, and automated static perimetry (Humphrey Visual Field Analyzer 30-2 [HFA 30-2]; Humphrey Instruments, San Leandro, CA, USA) demonstrated no visual field defects in either eye (Fig. 2A,B), he was diagnosed with OAG because his maximum known IOP was remarkably high $(36 \mathrm{mmHg})$.
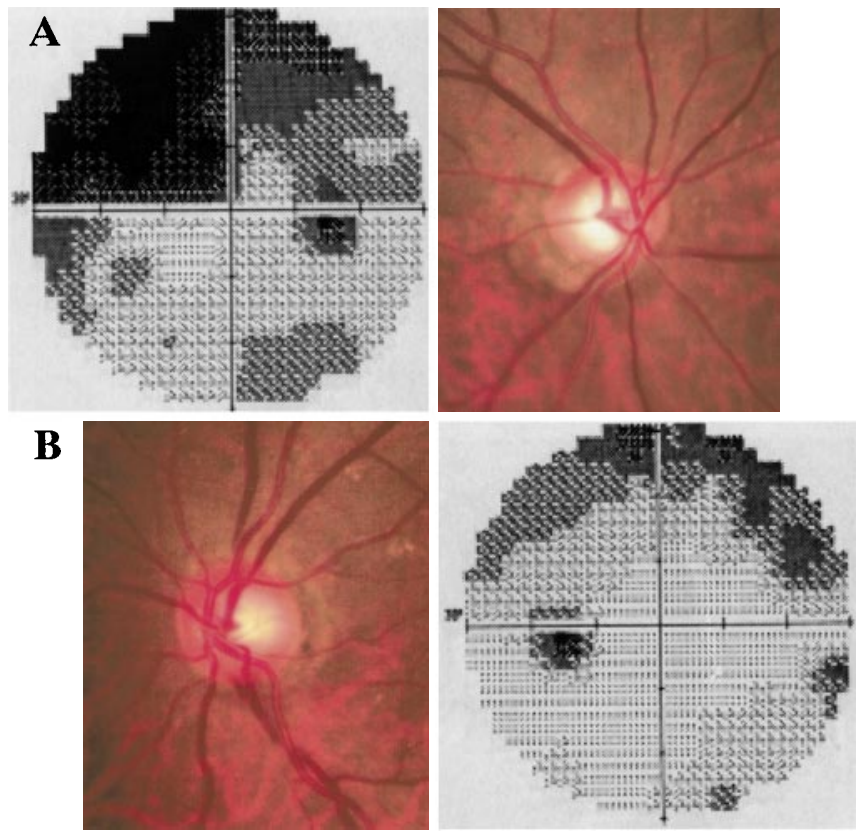

Fig. 3A,B. Visual field and optic disc of patient (case 2) with Arg158Gln in the MYOC/TIGR protein. A Right eye; B left eye. Glaucomatous disc cupping and visual field defect were observed. Her maximum known IOP was $16 \mathrm{mmHg}$

Case 2

A 76-year-old woman was seen in 1998, when she complained of visual loss. She had no family history of glaucoma. At the initial examination at the age of 74 , her best corrected visual acuity in the right eye had been hand motion, because of cataract, and 1.0 in the left. After cataract surgery, her best corrected visual acuity in the right eye improved to 1.0. Ophthalmoscopic examination revealed moderately excavated optic discs in both eyes, with a splinter hemorrhage at the inferotemporal edge of the left optic disc (Fig. 3A,B). HFA30-2 showed an altitudinal visual field defect in the right eye and an arcuate defect in the left eye (Fig. 3A,B). Gonioscopy revealed a widely open angle in both eyes. The IOP never exceeded $16 \mathrm{mmHg}$, without medication, and the visual field defects were stable during the following 2 years. An X-ray computerized tomography study revealed no signs of intracranial disease that would cause visual field defects. She was diagnosed with OAG without increased IOP.

\section{Case 3}

A 56-year-old man with mild cataract with no family history of glaucoma served as a normal control subject. His best corrected visual acuity was 1.0 in each eye. No signs of glaucoma were found in the optic disc in either eye, with an IOP of $13 \mathrm{mmHg}$ in his right eye and an IOP of $15 \mathrm{mmHg}$ in his left eye. 
The family members

The family members of these three individuals (cases 1, 2, and 3) were requested to undergo ophthalmoscopic and genetic studies. Only one of the five children of case 2, a 49year-old man, was studied. His IOP was $14 \mathrm{mmHg}$ in the right eye and $13 \mathrm{mmHg}$ in the left eye, with no glaucomatous changes in the optic disc in either eye. He did not have the Arg158Gln sequence change in the MYOC/TIGR protein.

\section{Discussion}

Twelve amino acid sequence changes in the MYOC/TIGR protein have been reported in Japanese patients with OAG (Suzuki et al. 1997; Fingert et al. 1999; Yokoyama et al. 1999; Kawase et al. 2000; Kubota et al. 2000). Of these 12 sequence changes, 5 were found only in Japanese. Arg158Gln may also be a specific sequence change in Japanese, because it has not been found, despite the screening of more than 2000 patients with OAG and more than 1000 control subjects, in other ethnic groups (Adam et al. 1997; Stoilova et al. 1997, 1998; Allingham et al. 1998; Angius et al. 1998; Brezin et al. 1998; Kennan et al. 1998; Mansergh et al. 1998; Michels-Rautenstrauss et al. 1998; Morissette et al. 1998; Richards et al. 1998; Wiggs et al. 1998; Damji et al. 1999; Fingert et al. 1999; Yoon et al. 1999; Lam et al. 2000).

Arg158Gln was reported as a probable disease-causing mutation because it has previously been found only in a 12year-old OAG patient without increased IOP (Kubota et al. 2000). The MYOC/TIGR protein contains an LZM, which consists of two subgroups (amino acid residues 85-99 and 117-166) in which leucine residues appear three and eight times, respectively, at every seventh position (Adam et al. 1997). Arg158Gln occurs in the latter subgroup of LZM and may be responsible for $\mathrm{OAG}$, by preventing the normal function of the LZM by altering the charge in this motif region. The LZM is considered to play an important role in the interaction between proteins, in polymerization as well as dimerization (Alber 1992). Previous studies have reported that kidney renin-binding protein with mutations in the LZM neither bound to renin nor formed a homodimer (Inoue et al. 1991), and that mutations in the LZM of human immunodeficiency virus type 1 gp41 dominantly inhibited infectious virus production (Chen et al. 1998). Because MYOC/TIGR proteins are thought to form homodimers (Nguyen et al. 1998), it is possible that Arg158Gln may interfere with their dimerization.

However, in this study, Arg158Gln was found not only in two OAG patients but also in a 56-year-old control subject without glaucoma, which means that Arg158Gln is probably a rare non-disease-causing polymorphism that just happens to alter the amino acid structure of the MYOC/TIGR protein, as it was found in a control subject. Mouse and rat have Gln in this position, and this observation supports the nondisease-causing polymorphic nature of this amino acid change in codon 158.
Although these findings suggest that Arg158Gln in the LZM region of the MYOC/TIGR protein is not responsible for $\mathrm{OAG}$, despite its important role in this region, other missense sequence changes without Arg158Gln in this motif region, especially a sequence change in the leucine residue composing zipper-like motif, may be responsible for OAG. Further investigation will be needed to elucidate the effect of amino acid sequence changes in the LZM region of the MYOC/TIGR protein.

Acknowledgments The authors thank Tamiyasu Shimamiya and Rumiko Ito, the Center for Medical Research, Yamanashi Medical University, for technical assistance. This work was supported in part by a Grant-in-Aid (number 12670348) from the Ministry of Education, Science, Sports, and Culture of Japan.

\section{References}

Adam MF, Belmouden A, Binisti P, Brezin AP, Valtot F, Bechetoille A, Dascotte JC, Copin B, Gomez L, Chaventre A, Bach JF, Garchon HJ (1997) Recurrent mutations in a single exon encoding the evolutionarily conserved olfactomedin-homology domain of TIGR in familial open-angle glaucoma. Hum Mol Gen 6:2091-2097

Alber T (1992) Structure of the leucine zipper. Curr Opin Genet Dev 2:205-210

Allingham RR, Wiggs JL, De La Paz MA, Vollrath D, Tallett DA, Broomer B, Jones KH, Del Bono EA, Kern J, Patterson K, Haines JL, Pericak-Vance MA (1998) Gln368STOP myocilin mutation in families with late-onset primary open-angle glaucoma. Invest Ophthalmol Vis Sci 39:2288-2295

Alward WL, Fingert JH, Coote MA, Johnson AT, Lerner SF, Junqua D, Durcan FJ, McCartney PJ, Mackey DA, Sheffield VC, Stone EM (1998) Clinical features associated with mutations in the chromosome 1 open-angle glaucoma gene (GLC1A). N Engl J Med 338: $1022-1027$

Angius A, De Gioia E, Loi A, Fossarello M, Sole G, Orzalesi N, Grignolo F, Cao A, Pirastu M (1998) A novel mutation in the GLC1A gene causes juvenile open-angle glaucoma in four families from the Italian region of Puglia. Arch Ophthalmol 116:793797

Bikle DD, Munson S, Morrison N, Eisman J (1993) Zipper protein, a newly described tropomyosin-like protein of the intestinal brush border. J Biol Chem 268:620-626

Brezin AP, Adam MF, Belmouden A, Lureau MA, Chaventre A, Copin B, Gomez L, De Dinechin SD, Berkani M, Valtot F, Rouland JF, Dascotte JC, Bach JF, Garchon HJ (1998) Founder effect in GLC1A-linked familial open-angle glaucoma in Northern France. Am J Med Genet 76:438-445

Chen SS, Lee SF, Hao HJ, Chuang CK (1998) Mutations in the leucine zipper-like heptad repeat sequence of human immunodeficiency virus type $1 \mathrm{gp} 41$ dominantly interfere with wild-type virus infectivity. J Virol 72:4765-4774

Damji KF, Song X, Gupta SK, Gao J, Rock W, Bulman DE (1999) Childhood-onset primary open angle glaucoma in a Canadian kindred: clinical and molecular genetic features. Ophthalmic Genet 20: 211-218

Fingert JH, Heon E, Liebmann JM, Yamamoto T, Craig JE, Rait J, Kawase K, Hoh ST, Buys YM, Dickinson J, Hockey RR, WilliamsLyn D, Trope G, Kitazawa Y, Ritch R, Mackey DA, Alward WL, Sheffield VC, Stone EM (1999) Analysis of myocilin mutations in 1703 glaucoma patients from five different populations. Hum Mol Gen 8:899-905

Inoue H, Takahashi S, Fukui K, Miyake Y (1991) Leucine zipper motif in porcine renin-binding protein (RnBP) and its relationship to the formation of an RnBP-renin heterodimer and an RnBP homodimer. J Biol Chem 266:11896-11900

Kawase K, Kawase C, Udo M, Yoh M, Yamamoto T, Kitazawa Y, Fingert JH, Alward WL, Stone EM, Semina EV (2000) Genetic variation in five glaucoma-related genes in Japanese patients with 
juvenile glaucoma and congenital glaucoma (abstract). Invest Ophthalmol Vis Sci 41:S824

Kennan AM, Mansergh FC, Fingert JH, Clark T, Ayuso C, Kenna PF, Humphries P, Farrar GJ (1998) A novel Asp380Ala mutation in the GLC1A/myocilin gene in a family with juvenile onset primary open angle glaucoma. J Med Genet 35:957-960

Kubota R, Noda S, Wang Y, Minoshima S, Asakawa S, Kudoh J, Mashima Y, Oguchi Y, Shimizu, N (1997) A novel myosin-like protein (myocilin) expressed in the connecting cilium of the photoreceptor: molecular cloning, tissue expression, and chromosomal mapping. Genomics 41:360-369

Kubota R, Mashima Y, Ohtake Y, Tanino T, Kimura T, Hotta Y, Kanai A, Tokuoka S, Azuma I, Tanihara H, Inatani M, Inoue Y, Kudoh J, Oguchi Y, Shimizu N (2000) Novel mutations in the myocilin gene in Japanese glaucoma patients. Hum Mutat, Mutation in Brief \#355 Online: http://humu.edoc.com/mutbr1.html

Lam DSC, Leung YF, Chua JKH, Baum L, Fan DSP, Choy KW, Pang CP (2000) Truncations in the TIGR gene in individuals with and without primary open-angle glaucoma. Invest Ophthalmol Vis Sci 41:1386-1391

Mansergh FC, Kenna PF, Ayuso C, Kiang AS, Humphries P, Farrar GJ (1998) Novel mutations in the TIGR gene in early and late onset open angle glaucoma. Hum Mutat 11:244-251

Michels-Rautenstrauss KG, Mardin CY, Budde WM, Liehr T, Polansky J, Nguyen T, Timmerman V, Van Broeckhoven C, Naumann GO, Pfeiffer RA, Rautenstrauss BW (1998) Juvenile open angle glaucoma: fine mapping of the TIGR gene to 1q24.3-q25.2 and mutation analysis. Hum Genet 102:103-106

Morissette J, Clepet C, Moisan S, Dubois S, Winstall E, Vermeeren D, Nguyen TD, Polansky JR, Cote G, Anctil JL, Amyot M, Plante M, Falardeau P, Raymond V (1998) Homozygotes carrying an autosomal dominant TIGR mutation do not manifest glaucoma. Nat Genet 19:319-321

Nguyen TD, Chen P, Huang WD, Chen H, Johnson D, Polansky JR (1998) Gene structure and properties of TIGR, an olfactomedinrelated glycoprotein cloned from glucocorticoid-induced trabecular meshwork cells. J Biol Chem 273:6341-6350
Quigley HA (1996) Number of people with glaucoma worldwide. Br J Ophthalmol 80:389-393

Richards JE, Ritch R, Lichter PR, Rozsa FW, Stringham HM, Caronia RM, Johnson D, Abundo GP, Willcockson J, Downs CA, Thompson DA, Musarella MA, Gupta N, Othman MI, Torrez DM, Herman SB, Wong DJ, Higashi M, Boehnke M (1998) Novel trabecular meshwork inducible glucocorticoid response mutation in an eightgeneration juvenile-onset primary open-angle glaucoma pedigree. Ophthalmology 105:1698-1707

Stoilova D, Child A, Brice G, Crick RP, Fleck BW, Sarfarazi M (1997) Identification of a new "TIGR" mutation in a family with juvenileonset primary open angle glaucoma. Ophthalmic Genet 18:109118

Stoilova D, Child A, Brice G, Desai T, Barsoum-Homsy M, Ozdemir N, Chevrette L, Adam MF, Garchon HJ, Pitts Crick R, Sarfarazi M (1998) Novel TIGR/MYOC mutations in families with juvenile onset primary open angle glaucoma. J Med Genet 35:989-992

Stone EM, Fingert JH, Alward W, Nguyen TD, Polansky JR, Sunden S, Nishimura D, Clark AF, Nystuen A, Nichols BE, Mackey DA, Ritch R, Kalenak JW, Craven ER, Sheffield VC (1997) Identification of a gene that causes primary open angle glaucoma. Science 275:668670

Suzuki Y, Shirato S, Taniguchi F, Ohara K, Nishimaki K, Ohta S (1997) Mutations in the TIGR gene in familial primary open-angle glaucoma in Japan. Am J Hum Genet 61:1202-1204

Wiggs JL, Allingham RR, Vollrath D, Jones KH, De La Paz M, Kern J, Patterson K, Babb VL, Del Bono EA, Broomer BW, PericakVance MA, Haines JL (1998) Prevalence of mutations in TIGR/ myocilin in patients with adult and juvenile primary open-angle glaucoma. Am J Hum Genet 63:1549-1552

Yokoyama A, Nao-i N, Date Y, Nakazato M, Chumann H, Chihara E, Sawada A, Matsukura S (1999) Detection of a new TIGR gene mutation in a Japanese family with primary open angle glaucoma. Jpn J Ophthalmol 43:85-88

Yoon SJ, Kim HS, Moon JI, Lim JM, Joo CK (1999) Mutations of the TIGR/MYOC gene in primary open-angle glaucoma in Korea (letter). Am J Hum Genet 64:1775-1778 